\title{
IMPLEMENTASI ISLAMIC PARENTING DALAM MEMBENTUK KARAKTER ANAK USIA DINI DI RA AT-TAQWA KOTA CIREBON
}

\author{
Ahmad Yani \\ Dosen Jurusan PGRA IAIN Syekh Nurjati Cirebon \\ email : ahmad_habib75@yahoo.com \\ Ery Khaeriyah \\ Dosen Jurusan PGRA IAIN Syekh Nurjati Cirebon \\ email : erykhaeriyah21@yahoo.com \\ Maulidya Ulfah \\ Dosen Jurusan PGRA IAIN Syekh Nurjati Cirebon \\ email : ulfah.003@gmail.com
}

Article received: 20 Maret 2017 Review process: 21 Maret 2017

Article published: 30 Maret 2017

\begin{abstract}
Abstrak
Masa keemasan seorang anak, khususnya pertumbuhan dan perkembangan otaknya (golden age), menurut para pakar (neurosains) adalah saat mereka berada di usia dini atau setara dengan usia sekolah taman kanak-kanak atau RA, yaitu sekitar 4-7 tahun. Oleh karenanya, di usia ini pendidikan bagi seorang anak menjadi penting, di samping itu, pemahaman orang tua tentang bagaimana sebaiknya mendidik anak (parenting) di masa usia TK/RA juga menjadi bagian yang sangat penting. Oleh karena itu, penelitian ini bertujuan untuk mengetahui bagaimana pelaksanaanIslamic Parenting Dalam Membentuk Karakter Anak Usia Dini Di RA At-Taqwa Kota Cirebon yang merupakan salah satu RA unggulan dan siswa-siswinya memiliki banyak prestasi, serta untuk mengetahuimasalah-masalah yang dihadapi orangtua dalam menerapkan pola pengasuhan anak usia dini secara islami, tindakan apa yang dilakukan orangtua dalam mengatasi masalah-masalah tersebut dan dampak Islamic Parenting terhadap karakter anak usia dini. Penelitian ini menggunakan pendekatan kualitatif, sedangkan pengumpulan data dalam penelitian ini dilakukan dengan menggunakan teknik observasi, wawancara mendalam, telaah dokumentasi,dan Focus Grup Discussion. Pengumpulan data primer yang dilakukan melalui wawancara mendalam agar dapat menggali lebih banyak informasi dari informan dilakukan kepada kepala sekolah, Ketua Persatuan Orang tua Murid dan Guru, serta orang tua/wali murid. Selain itu, pengumpulan data sekunder diperoleh melalui pencatatan dokumen-dokumen RA yang mendukung kegiatan pembelajaran RA. Hasil Penelitian ini menunjukkan bahwa 1) Islamic Perenting di RA At-Taqwa adalah kegiatan orang tua/wali murid RA yang difasilitasi pihak sekolah/RA untuk mengadakan kegiatan presentasi ilmiah ataupun pengkajian tentang berbagai tema terkait pola pendidikan dan pengasuhan anak usia dini (RA), dengan tujuan untuk memberikan tambahan wawasan pengetahuan teoritik dan pengalaman praktis kepada orang tua/wali murid dalam mendidik anak-anak mereka. Kegiatan ini dilaksanakan oleh Persatuan Orang tua Murid dan Guru (POMG) setiap bulan sekali pada hari Sabtu minggu ke-4, dimulai jam 08.00 sd. Jam 10.00 WIB di RA setempat, dengan menghadirkan narasumber yang dianggap kompeten dibidangnya. 2) Orang tua/wali murid RA dalam melakukan pola pengasuhan anak terhadap anak-anak mereka (usia dini/RA) tidak luput dari berbagai kendala yang dihadapi, antara lain anak tidak mau belajar; anak tidak mau

Implementasi Islamic Parenting Dalam Membentuk Karakter Anak Usia Dini

Ahmad Yani, Ery Khaeriyah, Maulidya Ulfah
\end{abstract}


sholat; anak selalu menunggu perintah orang tua; Tidak mau mengikuti perintah orang tua;Kondisi anak kurang moods; Anak-anak mengantuk;Anak malas-malasan;Anak merasa kecapean; 3) Langkah-langkah yang dilakukan orang tua/wali murid RA At-Taqwa Kota Cirebon, dalam mengatasi berbagai kendala sebagaimana tersebut di atas, berdasarkan wawasan dan pengalaman yang orang tua/wali murid lakukan antara lain dengan cara memahami karakter anak, menguatkan kesabaran, dengan strategi membujuk anak secara pelan-pelan, memberikan pengertian dan penjelassan dengan baik, memberikan reward dan punishment, memberikan contoh teladan dan pembiasaan, memahami dan mengerti kondisi anak. 3) Dampak yang dirasakan orang tua/wali murid RA At-Taqwa setelah mengikuti kegiatan Islamic parenting dalam pembentukan karakter anak usia dini (RA), antara lain mereka merasa terbantu memiliki pola untuk lebih mendisiplinkan anak anak, dapat mengokohkan persaudaraan/silaturrahim, saling sharing pengalaman dalam melakukan pola pengassuhan anak antara orang tua yang satu dengan yang lainnya, dan membantu proses pembentukan kebiasaan-kebiasaan positif.

\section{Kata Kunci: Islamic Parenting, Pembentukan Karakter, Anak Usia Dini}

\section{A. PENDAHULUAN}

Anak adalah anugerah sekaligus amanah yang diberikan Allah SWT. kepada setiap orang tua. Berbagai cara dan upaya dilakukan orang tua agar dapat melihat anak-anaknya tumbuh dan berkembang sebagaimana mestinya. Namun seringkali harapan tidak sesuai dengan kenyataan, entah karena terhambatnya komunikasi atau minimnya pengetahuan orangtua tentang bagaimana islam memberikan tuntunan dan pedoman tentang memperlakukan anak sesuai dengan proporsinya. Rasulullah Saw. mengajarkan bahwa ada dua hal potensi yang akan mewarnai dan membentuk kepribadian anak yaitu orangtua yang melahirkan dan lingkungan yang membesarkannya.

Mengutip pernyataan Imam al-Ghazali bahwa pendidikan tidak hanya terbatas pada pengajaran semata. Si penanggung jawab berkewajiban mengawasi anak dari hal sekecil dan sedini mungkin. Ia jangan sampai menyerahkan anak yang berada di bawah tanggung jawabnya untuk diasuh dan disusui kecuali oleh perempuan yang baik, agamis, dan hanya memakan sesuatu yang halal.

Anak adalah aset. Ia adalah penerus kedua orang tuanya. Namun, ia bukan hanya aset bagi kedua orang tua, tapi juga aset bagi suatu masyarakat dan bangsa, شُبان اليوم رجال الغد, pemuda hari ini adalah pemimpin hari esok di masa yang akan datang. Oleh karena itu, untuk menjadi generasi penerus yang baik dan handal, seorang anak perlu memiliki dan dibekali berbagai hal, baik pengetahuan yang handal, kecakapan dan keterampilan yang mumpuni, maupun akhlak yang baik. 
Pengetahuan dibutuhkan agar seorang anak dapat bertahan hidup, memberi manfaat, dan tidak dibodohi oleh orang lain. Kecakapan dan keterampilan juga dibutuhkan seorang anak bagi masa depannya agar ia dapat mandiri dan tidak bergantung pada orang lain, mampu bertahan hidup, dan sebagainya. Karakter yang baik, atau dalam bahasa Islam disebut dengan Akhlak yang baik juga dibutuhkan karena merupakan kunci keberhasilan berkat kepercayaan yang dihasikan dari orang di sekitarnya.

Akhlak yang baik mencari ruh yang utama, karena sehebat apapun seorang anak memiliki pengetahuan maupun keterampilan, jika ia tidak memiliki akhlak yang baik untuk menjamin dirinya dapat dipercaya, maka ia akan hancur binasa. Tanpa akhlak, sehebat apapun kesuksesan yang diraihnya, ia akan tetap hancur akibat kesalahan yang dilakukannya karena tidak memiliki dasar karakter atau akhlak yang kuat. Pentingnya akhlak digambarkan oleh ungkapan berikutsebagaimana Syauqi Bey berkata dalam syairnya (Kahar Mansur, 1994: 3):

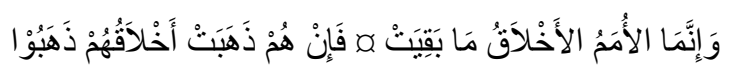

Artinya: "Sesungguhnya kejayaan suatu umat (bangsa) terletak pada akhlaknya selagi mereka berakhlak dan berbudi perangai utama, jika pada mereka telah hilang akhlaknya, maka jatuhlah umat (bangsa) itu."

Dalam ajaran Islam, pembentukan karakter seorang anak menjadi tanggung jawab orang tua sebagai lingkungan yang memiliki pengaruh yang sangat besar. Hadits Nabi dalam Musnad Ahmad, j. 20, h. 87:

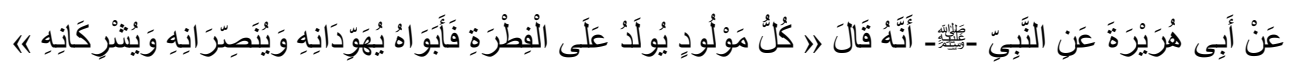

Artinya: "Diriwayatkan dari Abu Hurairah ra, dari Nabi Muhammad Saw, bahwasanya beliau bersabda: Setiap anak dilahirkan dalam keadaan fitrah, maka kedua orang tuanyalah yang menjadikannya Yahudi, Nashrani, dan Majusi”

Pentingnya peranan orang tua, kini memunculkan satu istilah, Parenting, yang diartikan sebagai proses menjadi orang tua, dimana dimaksudkan di sini adalah bagaimana orang tua menjalankan tugas dan tanggung jawabnya sebagai orang tua. Tugasnya tidak hanya melahirkan dan mengasuh atau membesarkan, namun yang lebih berat dari itu adalah mendidik.Hanya saja, kenyataannya bahwa sebagai orang tua, banyak yang tidak faham tentang apa, siapa, dan bagaimana menjadi orang tua, apalagi jika dikaitkan untuk mengasuh dan membesarkan serta mendidik. Banyak orang tua yang hanya faham mengasuh dan membesarkan dengan penuh kasih sayang, tapi tidak faham bagaimana mendidik dengan penuh kasih sayang. Banyak juga orang tua yang berharap anaknya sukses namun dalam arti pintar, kaya, bahagia, tanpa faham apa 
sesungguhnya kesuksesan yang sebaiknya dimiliki seorang anak dan bagaimana cara membuat seorang anak sukses.

Selain itu, kita banyak mengambil landasan pendidikan anak dari konsep barat, tanpa tahu bagaimana konsep dan petunjuk Al-Qur'an maupun Hadits sebagai basis keagamaan. Dasar tujuan hidup dalam pandangan agama sering kita lupakan, yang sering muncul adalah dasar tujuan hidup dalam konteks keduniaan, sehingga anak yang kita hasilkan seringkali memiliki karakter dan kemampuan yang kita tidak harapkan.Bisa jadi, munculnya kekerasan terhadap anak, atau anak yang mendapat cap "anak nakal" adalah akibat pemahaman yang keliru dari orang tua tentang bagaimana seharusnya bersikap terhadap seorang anak dan mempersiapkannya menjadi generasi terbaik.Masa keemasan seorang anak, khususnya pertumbuhan dan perkembangan otaknya (golden age), menurut para pakar (neurosains) adalah saat mereka berada di usia dini atau setara dengan usia sekolah taman kanak-kanak atau raudhatul athfal, yaitu sekitar 4-7 tahun. Oleh karenanya, di usia ini pendidikan bagi seorang anak menjadi penting, di samping itu, pemahaman orang tua tentang bagaimana sebaiknya mendidik anak (parenting) di masa usia TK/RA juga menjadi bagian yang sangat penting.

Sugito (2008) menyatakan bahwa ada beberapa prinsip pengasuhan orang tua yang berkaitan dengan pengembangan karakter. Prinsip dimaksud meliputi keteladanan diri, kebersamaan dengan anak dalam merealisasikan nilai moral, sikap demokratis, sikap terbuka dan jujur, dan kemampuan menghayati kehidupan anak, serta kesatuan kata dan tindakan. Tingkat penggunaan intensitas pada prinsip tersebut akan menghasilkan kepercayaan dan kewibawaan orang tua di mata anak. Kepercayaan dan kewibawaan yang tinggi akan memunculkan apresiasi anak pada orang tua, memiliki dampak munculnya nilai disiplin diri yang bersumber dari kata hati anak. Sebaliknya kepercayaan dan kewibawaan yang rendah akan menghasilkan apresiasi nilai disiplin secara nalar dan berdasarkan pada logika, tidak ada kepercayaan dan kewibawaan akan menghasilkan apresiasi nilai disiplin diri secara naluri.

Tujuan penelitian ini bertujuan untuk mengetahui pelaksanaan Islamic Parenting pada anak usia dini di RA At-Taqwa Kota Cirebon, mengidentifikasi masalah-masalah yang dihadapi orangtua dalam menerapkan pola pengasuhan anak usia dini secara islami, mengidentifikasi tindakan yang dilakukan orangtua dalam mengatasi masalah-masalah yang muncul dalam pengasuhan anak secara islami dan menjelaskan dampak Islamic Parenting terhadap karakter anak usia dini. 
Hasil penelitian ini mempunyai manfaat yang dapat digunakan sebagai informasi atau kontribusi baru bagi pengembangan penelitian di bidang pola pengasuhan dalam lingkup pendidikan anak usia dini, sebagai bahan masukan untuk perbaikan dan peningkatan kualitas pengasuhan anak usia dini di TK/RA serta dapat diterapkan sebagai model pengasuhan yang islami dalam keluarga dan manfaat kepustakaan yaitu dapat menjadi salah satu karya ilmiah yang dapat menambah koleksi pustaka yang bermanfaat bagi pendidik khususnya dan masyarakat pada umumnya.

Penelitian ini menggunakan pendekatan kualitatif dengan rancangan studi kasus tunggal (one case study) yang terjadi pada orangtua yang memiliki anak usia 4-6 tahun yang sekolah di RA At-taqwa Kota Cirebon. Inti permasalahan yang hendak dipecahkan melalui rancangan studi kasus ini adalah mengidentifikasi masalah-masalah yang dihadapi orang tua dalam mengasuh anak dilanjutkan pada tindakan yang dilakukan oleh orangtua dalam memecahkan masalah tersebut serta dampak yang timbul dari tindakan yang telah diberikan.

Pengumpulan data primer dalam penelitian ini dilakukan melalui wawancara mendalam agar dapat menggali lebih banyak informasi dari informan yang dilakukan kepada kepala sekolah, Ketua Persatuan Orang tua Murid dan Guru, serta orang tua yang memiliki anak usia 4 - 6 tahun di RA At-Taqwa Kota Cirebon. Pengumpulan data sekunder diperoleh melalui pencatatan dokumen-dokumen RA, arsip RA, portofolio anak, serta dokumen lain yang mendukung kegiatan pembelajaran RA. Data sekunder digunakan sebagai data penunjang dan pelengkap dari data primer yang ada relevensinya dengan keperluan penelitian.

Pengumpulan data dalam penelitian ini dilakukandengan menggunakan teknik Observasi, Wawancara, telaah dokumentasi, Focus Group Discussion (FGD). Adapun lokasi penelitian ini dilaksanakan di RA At-Taqwa Kota Cirebon yang dilaksanakan pada bulan Mei sampai dengan Nopember 2016

\section{B. PEMBAHASAN}

\section{Islamic Parenting (Pengasuhan anak dalam Islam)}

Islamic Parenting adalah dua kata yang berasal dari Bahasa Inggris, dimana Islamic merupakan kata sifat (adjective) bagi parenting. Islamic Parenting dalam bahasa Indonesia diterjemahkan dengan Parenting Islami. Kata "Parenting" mempunyai kata dasar yaitu parent yang dalam bahasa Inggris berarti orang tua.. Penggunaan kata "parenthing" untuk aktifitasaktifitas orang tua di sini karena memang saat ini belum ada kata yang tepat.yang sepadan dalam bahasa Indonesia. Mona Ratuliu (2015:16), mengutip teori yang diungkapkan oleh Martin 
Davies, seorang profesor Social Work di Universitas Of East Anglia, Norwich, Inggris, menyimpulkan bahwa parenthink (parenthing) pada dasarnya adalah pola asuh dan pendidikan sejak anak lahir sehingga anak telah memenuhi kriteria untuk disebut sebagai pribadi yang dewasa, bukan hanya dewasa secara fisik, namun juga dewasa secara mental atau psikologis. Pendidikan keorangtuaan adalah upaya peningkatan/penguatan pengasuhan, perlindungan, dan pendidikan yang dilaksanakan oleh keluarga untuk mendukung pembelajaran anak usia dini di lembaga PAUD (Solihin. Pengertian Parenting Atau Pendidikan Keorangtuaan). Ratna Megawangi (2007: 9) menjelaskan bahwa parenting itu merujuk pada suasana kegiatan belajar mengajar yang menekankan'kehangatan'bukan kearah suatu pendidikan satu arah atau tanpa emosi. Istilah 'parenting` di sini diartikan bahwa pendidikan akan lebih memeberikan hasil maksimal dengan suasana yang ada dalam keluarga.

Parenthing ialah upaya pendidikan yang dilaksanakan oleh keluarga dengan memanfaatkan sumber-sumber yang tersedia dalam keluarga dan lingkungan yang berbentuk kegiatan belajar secara mandiri. Parenthing sebagai proses interaksi berkelanjutan antara orang tua dan anak-anak mereka yang meliputi aktifitas-aktifitas memberi makan (nourishing), memberi petunjuk (guiding), melindungi (protecting) anak-anak ketika mereka tumbuh kembang.

Berdasarkan pengertian-pengertian tersebut di atas, maka parenting adalah Pola asuh, pendidikan, dan interaksi antara orang tua dan anak dalam sebuah keluarga. Sedangkan kata Islamic jika dilihat dari pengertian secara harfiyah/bahasa berasal dari kata islam yang artinya damai, selamat, tunduk, dan bersih. Kata islam itu sendiri terbentuk dari 3 huruf yaitu sin, lam, mim yang bermakna dasar "selamat". Adapun secara istilah, Islam adalah agama yang diturunkan kepada Nabi Muhammad Saw., sebagai Nabi dan Rasul terakhir suri tauladan bagi seluruh umat manusia diakhir zaman.

Islamic Parenting ialah mempersiapkan generasi muda yang memiliki moral yang mengacu pada norma-norma islam dan membentuk generasi shalih dan shalihah. Oleh karena itu, hal ini dapat dilakukan sebelum anak lahir di dunia, bukan hanya ketika anak sudah lahir ke dunia ini. Konsep Islamic parenting mengajarkan bahwa pola asuh yang digunakan orang tua juga mencakup bagaimana orang tua mampu membentuk akhlaqul karimah terhadap anakanaknya. Ayat Al-Qur'an yang berkaitan dengan itu adalah yang artinya "Dan (ingatlah) ketika Luqman berkata kepada anaknya, di waktu ia memberi pelajaran kepadanya: "Hai 
anakku, janganlah kamu mempersekutukan Allah, sesungguhnya mempersekutukan (Allah) adalah benar-benar kezaliman yang besar". (Q.S Luqman: 13)

Menurut Kamal Hasan, Islamic Parenting adalah suatu proses seumur hidup untuk mempersiapkan seseorang agar dapat mengaktualisasikan perannya sebagai khalifatullah di muka bumi ini. Dengan kesiapan tersebut, diharapkan memberikan sumbangan sepenuhnya terhadap rekontruksi dan pembangunan masyarakat dalam mencapai kebahagian dunia dan akhirat. Seperti halnya dengan Muhammad Natsir, menurutnya Islamic Parenting adalah pengasuhan yang berpusat pada tauhid. Artinya konsep tauhid harus dijadikan dasar pembinaan masyarakat. Dalam perspektif islam, mengasuh anak bukan hanya persoalan memberikan kebutuhan yang bersifat ragawi saja, lebih dari itu juga orang tua harus mengajarkan nilai-nilai islam kepada anak-anaknya (Muhammad Ali Muttaqin, 2015:44-45).

\section{Landasan dan Prinsip Islamic Parenting}

Firman Allah Swt dalam SuratAt-Tahrim: 6:

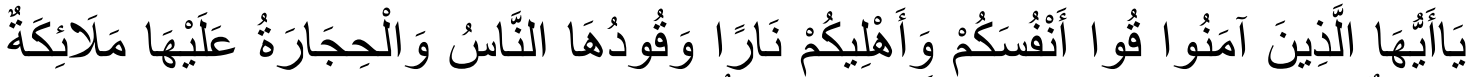

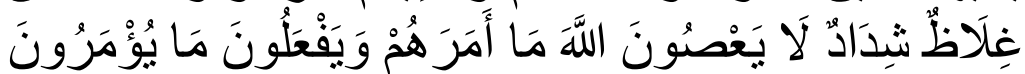

Artinya: "Hai orang-orang yang beriman, peliharalah dirimu dan keluargamu dari api neraka yang bahan bakarnya adalah manusia dan batu; penjaganya malaikat-malaikat yang kasar, keras, dan tidak mendurhakai Allah terhadap apa yang diperintahkan-Nya kepada mereka dan selalu mengerjakan apa yang diperintahkan."

Firman Allah Swt dalam Surat An-Nisa/4: 9:

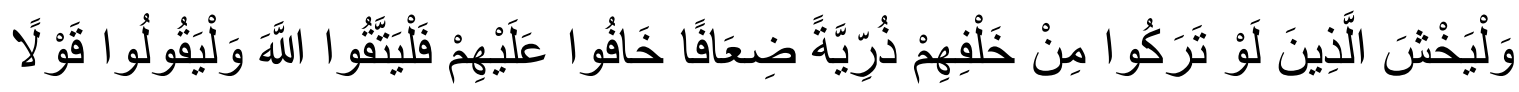

Artinya: "Dan hendaklah takut kepada Allah orang-orang yang seandainya meninggalkan di belakang mereka anak-anak yang lemah, yang mereka khawatir terhadap (kesejahteraan) mereka. Oleh sebab itu, hendaklah mereka bertakwa kepada Allah dan hendaklah mereka mengucapkan perkataan yang benar"

Dalam sebuah hadits (Shahih Muslim, J. 6, H. 7) disebutkan:

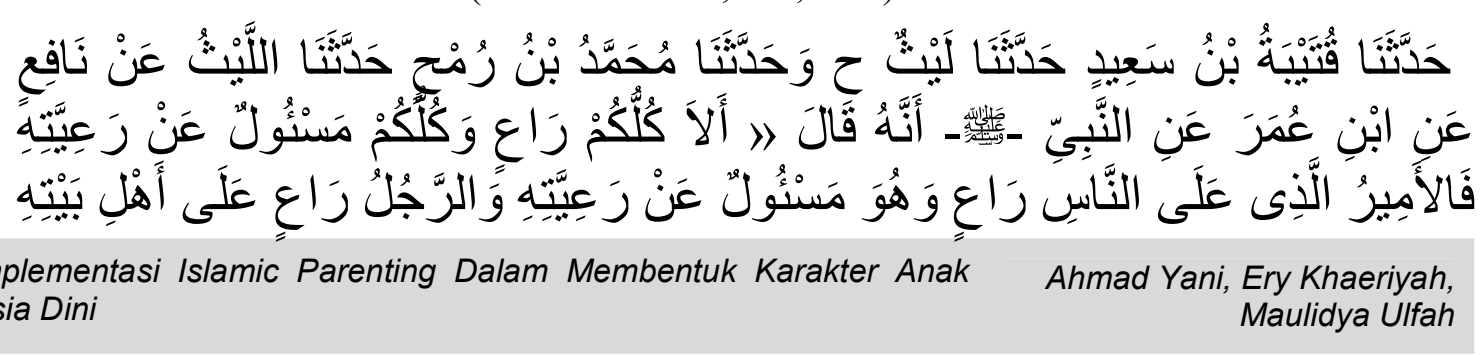




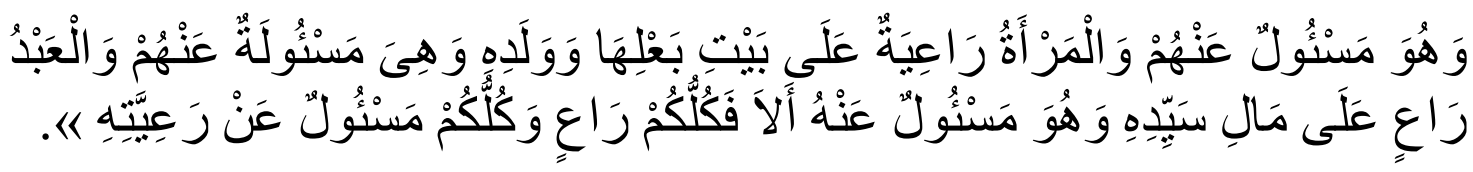

Artinya: "Kalian semua adalah pemimpin dan akan ditanya tentang kepemimpinan kalian. Seorang 'Amir adalah pemimpin dan dia akan ditanya tentang rakyatnya. Seorang lakilaki adalah pemimpin bagi anggota keluarganya dan dia akan ditanya tentang anggota keluarga yang dipimpinnya. Seorang perempuan adalah pemimpin dalam di rumah suaminya dan anaknya dan dia akan ditanya tentang mereka. Seorang hamba adalah pemimpin terhadap harta tuannya dan dia akan ditanya tentangnya. Ingatlah, kalian semua adalah pemimpin dan akan ditanya tentang kepemimpinan kalian”. (HR. Bukhari dan Muslim, dari Nafi' dari Abdullah bin Umar)

Pendidikan anak adalah tanggung jawab dan amanah yang besar. Wajib bagi para orang tua untuk bertakwa kepada Allah dalam urusan anak-anak mereka. Wajib bagi para orang tua untuk memberikan pendidikan dan bimbingan. Menumbuh-kembangkan mereka dalam akidah Islam, amalan-amalan Islam, dan akhlak-akhlak Islam. Para orang tua wajib membangun pondasi ketakwaan dan keshalehan agar anak-anak mengetahui dan mengamalkan apa yang menjadi hakhak Allah Jalla wa 'Ala pada diri mereka. Fungsi utama pendidikan kepada anak adalah melestarikan fitrah anak, yaitu fitrah kebenaran, fitrah tauhid, fitrah prilaku positif, dan sebagainya.

Sejak lahir anak telah diberikan insting atau kecenderungan pada kebaikan yang tertanam dalam dirinya dan berlanjut hingga masa akil baligh. Maka dari itu, program pendidikan kepada anak diharapkan lurus dan kokoh secara lestari dengan fitrah yang dibawa anak. Sejarah mencatat bahwa para Nabi pun sangat bersungguh-sungguh dalam mendidik anak-anak mereka dan memperhatikan keadaan mereka. Nabi Yaqub As. pernah bertanya kepada anak-anaknya, tujuannya adalah agar beliau merasa tenang dengan jalan hidup mereka yang tetap diatas tauhid setelah meninggalkannya. "apa yang akan disembah sepeninggalku?" dan beliau pun merasa senang ketika mendengar jawaban anak-anaknya. "Mereka berkata, 'Kami akan menyembah Tuhanmu dan Tuhan nenek moyangmu, Ibrahim, Ismail, dan Ishaq, Tuhan Yang Maha Esa dan kami hanya tunduk kepada-nya." (QS. Al-Baqarah [2]: 133).

\section{Prinsip pengasuhan anak}

Prinsip adalah sesuatu yang menjadi landasan atau fondasi dalam memilih cara bertindak. Karena itu, prinsip pengasuhan dapat diartikan sebagai landasan bagi dalam mengasuh anak. Berikut ini adalah tiga prinsip utama dalam pengasuhan anak yang diungkapkan Rudi Cahyono (2015: 19-28): 
a. Anak adalah subjek, bukan objek dalam pengasuhan

Anak adalah pusat dari perubahan. Meski pengasuhan bisa mengacu kepada individu, komunitas, atau masyarakat namun peran utama tetap dipegang oleh orangtua dan keluarga sebagai lingkaran terdekat dari anak. Meskipun demikian, bukan berarti anak hanya sekedar objek bagi para pengasuh atau bagi anggota keluarga yang lebih dewasa, akan tetapi ia menjadi actor utama atas diri mereka. Sebagai manusia yang sama-sama diciptakan oleh Tuhan seperti halnya orang dewasa, anak juga punya kemerdekaan berpikir, merasa, dan berprilaku. Artinya, anak-anak berhak meyakini dan menentukan pilihan atas perilakunya sendiri.

Dengan memegang prinsip ini, maka akan berpengaruh kepada perlakuan kita terhadap anak. Hal ini berarti juga akan mempengaruhi metode kita dalam melakukan proses pengasuhan. Dengan menempatkan anak sebagai subjek, maka orang dewasa akan melihat perkembangan alamiah anak. Orangtua berperan sebagai fasilitator agar potensi anak dikenal dan dapat berkembang dengan baik. Orangtua juga tidak menentukan tujuan atau cita-cita anak, tetapi membantu anak dalam menentukan atau memilih cita-citanya. Orangtua tidak mengarahkan dan menuntun langkah demi langkah, tetapi menerangi jalan anak sehingga ia dapat memilih arah yang benar.

\section{b. Pengasuhan bersifat dialogis}

Anak-anak bukan figure pasif, mereka adalah subjek yang punya kedudukan sama. Anakanak memang tidak sekuat orang dewasa karena itulah orang dewasa mengarahkannya. Hal ini bukan berarti anak harus pasif dan menurut begitu saja. Anak-anak mengamati apa yang dilakukan oleh orang dewasa, bahkan juga melakukannya, karena anak punya hak untuk berpikir, merasa, dan berbicara sesuai dengan caranya, ia tak harus banyak diberi perintah. Dalam pengasuhan yang bersifat dialogis, hal yang perlu dikurangi adalah pemberian perintah, penjelasan, nasihat,dan perludiperbanyak bertanya, cerita, serta contoh nyata.

c. Pengasuhan menjangkau keseluruhan diri anak

Anak adalah individu yang utuh. Anak-anak hidup dan berkembang dengan aspek lengkap yang terdiri dari fisik, kognisi, dan sosioemosional. Untuk itu, perlu diperhatikan pengasuhan anak dalam aspek-aspek tersebut.

\section{Pendekatan dan Model Islamic Parenting}

Pendekatan Islamic Parenting yang dapat diterapkan pada pendidikan Anak Usia Dini dengan metode Nabi menurut Syaikh Jamal Abdurrahman (2011:103-126) adalah sebagai berikut: (1) Menasihati dan mengajari saat berjalan bersama (2) Menarik perhatian anak dengan 
ungkapan yang lembut (3) Bahaya melarang anak-anak dari mainan (4) Tidak membubarkan anak yang sedang bermain (5) Tidak memisahkan anak dari keluarganya (6) Mengajarkan akhlak mulia (7) Mendoakan kebaikan, menghindari doa keburukan (8) Meminta izin berkenaan dengan hak mereka (9) Mengajari anak menyimpan rahasia (10) Makan bersama anak-anak sembari memberikan pengarahan dan meluruskan kekeliruan mereka.

a. Pembentukan Karakter

Pembentukan adalah usaha yang terwujud sebagai hasil suatu tindakan. Sedangkan karakter, secara etimologis, kata karakter (Inggris charakter) berasal dari bahasa yunani, kharassein yang berarti "to engrave" (Ryan dan Bohlin, 1999:5). Kata "to engrave" itu sendiri dapat diterjemahkan menjadi mengukir, melukis, memahatkan, atau menggoreskan (Echols dan Shadily, 1995:214). Arti ini sama dengan istilah "Karakter" dalam bahasa Inggris (Charakter) yang juga berarti mengukir, melukis, memahatkan, atau menggoreskan (Echols dan Shadily, 1995:214).

Berbeda dengan bahasa Inggris, dalam bahasa Indonesia "Karakter" diartikan sebagai tabiat, sifat-sifat kejiwaan, akhlak atau budi pekerti yang membedakan seseorang dengan orang lain. Arti karakter secara kebahasaan yang lain adalah huruf, angka, ruang atau simbol khusus yang dapat dimunculkan pada layar dengan papan ketik (Pusat Bahasa Depdiknas, 2008:682). Dengan demikian karakter adalah nilai-nilai yang unik baik yang terpatri dalam diri dan tertanam dalam perilaku (Kementrian Pendidikan Nasional, 2010). Artinya, orang yang berkarakter adalah orang yang berkepribadian, berperilaku, bersifat, atau berwatak, tertentu, dan watak disebut yang membedakan orang satu dengan lainnya. Sementara itu, Thomas Lickona, sebagaimana dikutip Marzuki mendefinisikan karakter ecara etimologissebagai “A reliable inner disposition to respon situation in a morally good way," karakter mengacupada serangkaian pengetahuan (Cognitives) sikap (Attitudes), dan motivasi (motivations), serta perilaku (Behaviors) dan keterampilan (Marzuki, 2011:470)

Dari pengertian secara etimologis dan terminologis di atas, dapat disimpulkan bahwa karakter merupakan nilai-nilai universal perilaku manusia yang meliputi seluruh aktivitas kehidupan, baik yang berhubungan dengan Tuhan, diri sendiri, maupun sesama manusia, maupun dengan lingkungan yang terwujud dalam pikiran, sikap, perasaan, perkataan, dan perbuatan berdasarkan norma-norma agama, hukum tata karma, budaya, dan adat istiadat. Berbagai pengertian karakter identik dengan kepribadian, atau dalam islam disebut dengan Akhlak. Imam Al-Ghazali memberikan definisi tentang akhlak sebagai berikut, "Al-Khuluq Implementasi Islamic Parenting Dalam Membentuk Karakter Anak Ahmad Yani, Ery Khaeriyah,
Usia Dini 
(Jamak Al-Akhlaq) ialah ibarat (sifat atau keadaan) dari perilaku yang konstan (tetap) dan meresap dalam jiwa, dari padanya tumbuh perbuatan-perbuatan dengan wajar dan mudah tanpa memerlukan pikiran dan pertimbangan" (Zainuddin, et al, 1991: 102).

Berdasarkan pengertian tersebut, maka hakikat akhlak menurut Al-Ghazali (Zainuddin, et al, 1991: 102-103) harus memenuhi dua syarat: (1) Perbuatan tersebut harus konstan, dilakukan berulangkali (continue) dalam bentuk yang sama, sehingga menjadi kebiasaan (habit forming). Maka seseorang yang memberikan hartanya hanya sekali-kal tidak dapat dikatakan sebagai (berakhlak) pemurah karena sifat tersebut belum tetap dan meresap dalam jiwa. (2) Perbuatan yang konstan tersebut harus tumbuh dengan mudah sebagai bentuk wujud refleksi jiwa tanpa pertimbangan dan pemikiran, yakni bukan karena adanya tekanan ataupun paksaan dari orang lain, atau pengaruh dan bujukan.

Maka pembentukan karakter adalah usaha atau suatu proses yang dilakukan untuk menanamkan hal positif pada anak yang bertujuan untuk membangun karakter yang sesuai dengan norma, agama dan kaidah moral dalam bermasyarakat yang menjadi ciri khas atau kepribadian yang membedakan orang satu dengan lainnya. Pembentukan akhlak sejalan dengan hadits Nabi Saw (Maktabah Asy-Syamilah):

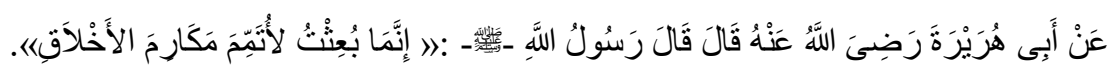

Artinya: "Diriwayatkan dari Abu Hurairah ra beliau berkata, Nabi Saw bersabda, 'Sesungguhnya aku diutus untuk menyempurnakan akhlak yang mulia'” (HR. Baihaqi: Hadits no 21301)

b. Tujuan Dasar Pembentukan Karakter

Pembentukan karakter bertujuan membentuk pribadi-pribadi yang toleran, senang membantu, gotong royong, bermental tangguh, dan kompetitif, serta senantiasa memiiki ketertarikan terhadap ilmu pengetahuan. Semua kemampuan ini dilandasi oleh keimanan dan ketakwaan kepada Allah Yang Maha Esa. Akhlak mulia merupakan tujuan pertama dalam upaya membentuk karakter anak(Asmawati, 2009: 90).

c. Faktor-faktor yang Mempengaruhi Pembentukan Karakter

Karakter merupakan salah satu poin penting yang menentukan keberhasilan seseorang. Adanya perbedaan karakter/kepribadian setiap individu sangatlah bergantung pada faktor-faktor yang memengaruhinya. Kepribadian terbentuk, berkembang, dan berubah seiring dengan proses sosialisasi yang dipengaruhi oleh faktor-faktor sebagai berikut. (a) Faktor Biologis (b) Faktor Geografis (c) Faktor Kebudayaan (d) Faktor Pengalaman Kelompok (d) Faktor Pengalaman Unik 
Sementara itu, V. Campbell dan R. Obligasi (1982) berpendapat bahwa beberapa faktor yang berpengaruh dalam pembentukan karakter seseorang adalah (a) Faktor keturunan (b) Pengalaman masa kanak-kanak (c) Pemodelan oleh orang dewasa atau orang yang lebih tua (d) Pengaruh lingkungan sebaya (e) Lingkungan fisik dan sosial (f) Subtansi materi di sekolah atau lembaga pendidikan lain (g) Media massa

Sedangkan menurut pendapat lainnya (Nurla Isna Aulillah,2015:63-66), ada lima faktor dari orang tua yang dapat mempengaruhi terbentuknya karakter anak, di antaranya adalah sebagai berikut: (a) Tempreman Dasar Orang Tua (b) Keyakinan Orang Tua (c) Pendidikan Orang Tua (d) Motivasi Hidup Orang Tua (f) Perjalanan Hidup Orang Tua. Selain itu, ada pendapat yang menyatakan bahwa ada tiga faktor yang sangat penting dalam proses pembentukan karakter anak yaitu faktor pendidikan (sekolah), lingkungan masyarakat, dan lingkungan keluarga.

Sementara itu Quraish Shihab (M. Fauzi Rachman, 2014:2-10) mengatakan bahwa anak didik dibentuk oleh empat faktor. Pertama, ayah yang berperan utama dalam membentuk kepribadian anak (bahkan, dalam Al-Qur'an hampir semua ayat berbicara tentang pendidikan anak, dan yang berperan adalah ayah), Kedua, yang membentuk kepribadiannya juga adalah ibu; Ketiga, apa yang dibacanya (ilmu); dan keempat, lingkungan. Jika semuanya baik, niscaya anak bisa baik, begitu juga sebaliknya.

Empat faktor ini belum tentu semuanya terwujud. Dalam kasus ketika Allah Swt. menetapkan nabi Muhammad Saw. sebagai utusan-Nya misalnya, kepribadian Nabi Muhammad Saw. tidaklah dibentuk oleh dominasi keempat faktor di atas, namun kepribadiaannya dibentuk langsung oleh Allah Swt. Sebab, jika diserahkan kepada masyarakat atau keluarga, maka ia tidak akan sempurna, bisa jadi keliru. Maka dari itu, Allah Swt. sendiri yang membentuknya, sedangkan masyarakat dan keluarga hanya diberi peranan yang sangat sedikit.

Selanjutnya Quraish Shihab mengatakan bahwa banyak pakar pendidikan mengakui terhadap dua faktor yang dapat mempengaruhi seseorang, yaitu genetik dan pendidikan. Walaupun mereka berbeda pendapat yang mana lebih dominan, namun yang jelas keduanya punya pengaruh. Rasulullah Saw. bersabda, "Bila ingin anak yang membawa namamu itu tumbuh kembang dengan baik, maka pilih-pilihlah tempat kamu meletakkan spermamu, karena gen itu menurun” (M. Fauzi Rachman, 2014:2-10).

d. Proses Pembentukan Karakter 
Pembentukan karakter pada anak tidak dapat dilakukan dengan cara dan waktu yang instan. Pembentukan karakter memerlukan waktu dan proses yang tepat agar anak mampu memahami dan mengimplementasikan dengan tepat juga. Untuk membentuk karakter seseorang juga melalui proses yang panjang. Proses pembentukan karakter pada anak bukanlah suatu proses sehari dua hari, namun bisa berbulan-bulan bahkan bertahun-tahun. Misalnya, seorang anak asal Indonesia yang mempunyai karakter buruk tinggal di Malaysia menyusul orang tuanya selama tiga tahun dengan harapan apabila ia kembali pulang ke Indonesia karakternya berubah menjadi anak yang baik, tetapi ternyata setelah tiga tahun dan kembali ke Indonesia karakter buruknya belum berubah. Hal ini membuktikan bahwa untuk merubah atau membentuk karakter baik pada anak membutuhkan waktu yang tidak sebentar.

Helmawati (2014: 166-169) menyatakan, metode yang umum dan telah teruji dapat membentuk anak berkarakter di antaranya adalah (a) Metode Keteladanan (b) Metode Percontohan (c) Metode Pembiasaan (d) Metode Pengulangan (e) Metode Pelatihan (f) Metode Motivasi. Adapun proses pembentukan karakter dapat ditempuh melalui tahapan sebagai berikut (a) Pengenalan (b) Pemahaman (c) Penerapan (d) Pengulangan /pembiasaan (e) Pembudayaan (f) Internalisasi menjadi karakter

\section{Pendidikan Anak Usia Dini}

Anak usia dini adalah individu yang mengalami proses pertumbuhan dan perkembangan yang sangat pesat, bahkan dikatakan sebagai lompatan perkembangan. Anak usia memiliki rentang usia yang sangat berharga dibandingkan dengan usia-usia selanjutnya karena perkembangan kecerdasannya sangat luar biasa. Usia tersebut merupakan fase kehidupan yang unik, dan berada pada masa proses perubahan berupa pertumbuhan, perkembangan, pematangan dan penyempurnaan, baik pada aspek jasmani maupun rohaninya yang berlangsung seumur hidup, bertahap dan berkesinambungan.

Anak usia dini adalah sekelompok anak yang berada dalam proses pertumbuhan dan perkembangan yang bersifat unik. Mereka memiliki pola pertumbuhan dan perkembangan yang khusus sesuai dengan tingkat perkembangannya (Mansur, 2005:34).

a. Ruang Lingkup Pendidikan Anak Usia Dini

Undang-Undang Republik Indonesia Nomor 20 Tahun 2003 tentang sistem Pendidikan pada pasal 1 ayat 14 yang mengatakan pendidikan anak usia dini adalah pendidikan yang diperuntukkan bagi anak sejak lahir sampai usia 6 tahun. Satuan Layanan PAUD, Pendidikan Anak usia dini diselenggarakan sebelum jenjang pendidikan dasar. Pendidikan anak usia dini 
dapat diselenggarakan melalui jalur pendidkan formal, nonformal, dan/atau informal. Pendidikan anak usia dini jalur pendidikan formal diselenggarakan pada Taman Kanak-kanak (TK), Raudhatul Athfal (RA), atau bentuk lain yang sederajat, rentang usia anak $4-6$ tahun. Pendidikan anak usia dini jalur pendidikan nonformal diselenggarakan pada Kelompok Bermain (KB) rentang usia anak $2-4$ tahun, Taman Penitipan Anak (TPA) rentang usia anak 3 bulan -2 tahun, atau bentuk lain yang sederajat (Satuan PAUD Sejenis/SPS) rentang usia anak $4-6$ tahun. Pendidikan anak usia dini jalur pendidikan informal diselenggarakan pada pendidikan keluarga ataupendidikan yang diselenggarakan oleh lingkungan, bagi orangtua yang mempunyai anak usia 0-6 tahun.

\section{b. Tahapan Perkembangan Anak}

Menurut para ahli, pada usia dini terjadi beberapa periode perkembangan. Pada setiap tahap perkembangan, seorang anak secara umum akan memperlihatkan ciri-ciri khusus atau karakteristik tertentu yang hampir sama. Menurut Comenius (Kartini Kartono, 1986: 34) periode perkembangan seorang anak terdiri empat tahap. Salah satu tahap tersebut adalah tahap 0-6 tahun atau periode sekolah-ibu. Periode 0-6 tahun disebut periode sekolah ibu, karena hampir semua usaha bimbingan, perawatan, pemeliharaan, dan pendidikan anak berlangsung di dalam keluarga yang dilakukan oleh ibu. Berikut akan diuraikan tentang fase-fase perkembangan anak usia dini.

1) Anak usia 0-2 tahun

Secara umum pada masa bayi anak usia 0-2 tahun, anak mengalami perubahan yang pesat bila dibandingkan dengan yang akan dialami pada fase-fase berikutnya. Anak sudah memiliki kemampuan dan keterampilan dasar yang berupa: keterampilan lokomotor (berguling, duduk, berdiri, merangkak dan berjalan), keterampilan memegang benda, penginderaan (melihat, mencium, mendengar dan merasakan sentuhan), maupun kemampuan untuk mereaksi secara emosional dan sosial terhadap orang-orang sekelilingnya.

Segala bentuk stimulus (verbal maupun nonverbal) dari orang lain akan mendorong anak untuk belajar tentang pengalaman-pengalaman sensori dan ekspresi perasaan meskipun anak belum mampu memahami kata-kata. Menurut Monks (1992:74-75) menyatakan bahwa stimulasi verbal ternyata sangat penting untuk perkembangan bahasa.Hal ini disebabkan kualitas dan kuantitas vokalisasi seorang anak dapat bertambah dengan pemberian reinforsement verbal. Stimulasi verbal yang terusmenerus juga akan memudahkan anak untuk belajar melafalkan suara-suara dan Dapat disimpulkan bahwa anak usia dini merupakan masa yang kritis dalam sejarah perkembangan manusia. Masa anak usia dini ini terjadi pada anak usia 0-6 tahun atau 
sampai anak mengikuti pendidikan pada jenjang pendidikan anak usia dini atau prasekolah. Pada masa ini terjadi pertumbuhan fisik dan psikis yang sangat pesat.gerakan-gerakan yang mengkomunikasikan suasana emosinya, seperti marah, cemas, tidak setuju dan lain-lain.

2) Anak usia 2-3 tahun

Pada fase ini anak sudah memiliki kemampuan untuk berjalan dan berlari.Anak juga mulai senang memanjat, meloncat, menaiki sesuatu dan lain sebagainya. Solehuddin (1997: 38) berpendapat bahwa pada anak usia 2-3 tahun lazimnya sangat aktif mengeksplorasi benda-benda di sekitarnya. Anak memiliki kekuatan observasi yang tajam. Anak juga menyerap dan membuat perbendaharaan bahasa baru, mulai belajar tentang jumlah, membedakan antara konsep satu dengan banyak dan senang mendengarkan cerita-cerita sederhana, yang kesemuanya diwujudkan anak dalam aktivitas bermain maupun komunikasi dengan orang lain. Kemampuan anak menguasi beberapa patah kata juga mulai berkembang.Anak mulai senang dengan perckapan walaupun dalam bentuk dan kalimat yang sederhana.Selain itu juga, sikap egosentrik anak sangat menonjol. Anak belum bisa memahami persoalan-persoalan yang dihadapinya dari sudut pemikiran orang lain. Anak cenderung melakukan sesuatu menurut kemauannya sendiri tanpa memperdulikan kemauan dan kepentingan orang lain. Sebagai contoh, anak sering merebut mainan dari orang lain jika anak menginginkannya.

3) Anak usia 3-4 tahun

Secara umum, anak pada fase ini masih mengalami peningkatan dalam berperilaku motorik, sosial, berfikir fantasi maupun kemampuan mengatasi frustasi.Untuk kemampuan motorik, anak sudah menguasai semua jenis gerakan-gerakan tangan, seperti memegang benda atau boneka.Akan tetapi sifat egosentriknya masih melekat.Tingkat frustasi anak juga cenderung menurun.Hal ini disebabkan adanya peningkatan kemampuan dalam mengatasi kesulitankesulitan yang dialaminya secara lebih aktif atau sudah ada sifat kemandirian anak. Pada usia ini anak memiliki kehidupan fantasi yang kaya dan menuntut lebih banyak kemandirian. Dengan kehidupan fantasi yang dimilikinya ini, anak akan memperlihatkan kesiapannya untuk mendengarkan cerita-cerita secara lebih lama, bahkan anak juga sudah dapat mengingatnya. Selanjutnya dengan sifat kemandirian yang dimilikinya mulai membuat anak tidak mau banyak diatur dalam kegiatannya.Pada aspek kognitif anak juga sudah mulai mengenal konsep jumlah, warna, ukuran dan lain-lain.

4) Anak usia 4-6 tahun 
Ciri yang menonjol anak pada usia ini adalah anak mempunyai sifat berpetualang (adventuroussness) yang kuat. Anak banyak memperhatikan, membicarakan atau bertanya tentang apa sempat ia lihat atau didengarnya. Minatnya yang kuat untuk mengobservasi lingkungan benda-benda di sekitarnya membuat anak senang bepergian sendiri untuk mengadakan eksplorasi terhadap lingkugan disekitarnya sendiri.Pada perkembangan motorik, anak masih perlu aktif melakukan berbagai aktivitas. Sejalan dengan perkembangan fisiknya, anak usia ini makin berminat terhadap teman sebayanya. Anak sudah menunjukkan hubungan dan kemampuan bekerjasama dengan teman lain terutama yang memiliki kesenangan dan aktivitas yang sama. Kemampuan lain yang ditunjukkan anak adalah anak sudah mampu memahami pembicaraan dan pandangan orang lain yang disebabkan semakin meningkatnya keterampilan berkomunikasi.

Berdasarkan tahap perkembangan tersebut, dapat disimpulkan bahwa anak usia dini merupakan masa yang kritis dalam sejarah perkembangan manusia. Masa anak usia dini ini terjadi pada anak usia 0-6 tahun atau sampai anak mengikuti pendidikan pada jenjang pendidikan anak usia dini atau prasekolah. Pada masa ini terjadi pertumbuhan fisik dan psikis yang sangat pesat.

\section{Program Islamic Parentingdalam Proses Pembentukan Karakter Anak Usia Dini di RA}

Keluarga sebagai unit sosial terkecil di masyarakat yang terbentuk atas dasar komitmen untuk mewujudkan fungsi keluarga, fungsi sosial, dan fungsi pendidikan harus benar-benar dioptimalkan sebagai mitra lembaga Pendidikan Anak Usia Dini. Oleh karena itu sekolah/lembaga PAUD perlu melahirkan program parenthing sebagai wadah komunikasi antar orang tua,di samping untuk memberikan sosialisasi terhadap program-program yang diselenggarakan oleh lembaga PAUD, karena secara umum tujuan program parenthing adalah mengajak para orang tua untuk bersama-sama memberikan yang terbaik untuk anak-anaknya.

Raudhatul Athfal yang merupakan lembaga pendidikan dalam lingkup PAUD perlu memiliki karakter yang khas dalam kegiatan parentingnya, yaitu berupa program kegiatan Islamic Parenting untuk mendukung orang tua sebagai pihak yang berperan paling penting dalam keluarga dalam proses pembentukan karakter anak agar sesuai dengan ajaran Islam sehingga memiliki akhlak yang mulia.

\section{Islamic Parenting dalam Proses Pembentukan Karakter Anak Usia Dini di RAAt-Taqwa}


RA At Taqwaterletak di pusat Kota Cirebon, tepatnya di jalan RA. Kartini No. 2 Kota Cirebon. RA At-Taqwa didirikan pada tahun 1990, merupakan lembaga pendidikan swasta yang memiliki jumlah siswa cukup banyak dari tahun ke tahun sejak didirikannya.Bahkan pada tahun 2007 RA At-Taqwa meraih predikat terakreditasi A. RA At-Taqwa memiliki visi "Mewujudkan anak-anak yang sholeh dan sholeha, cerdas kreatif dan kompetitif mandiri.", sedangkan misinya adalah "Membantu mengembangkan potensi dasar anak", mottonya "Cerdas dan Taqwa", dan tujuannya "Melaksanakan salah satu program pemerintah dalam mencerdaskan kehidupan bangsa dan menanamkan nilai-nilai keagamaan. Kurikulum yang digunakan RA At-Taqwa adalah kurikulum terpadu (Integrated Curriculum) antara Kurikulum Kemenag dan TK Diknas, memadukan pengetahuan agama dan umum secara seimbang. Dalam hal sarana dan prasarana, RA At-Taqwa telah memenuhi standar dan dalam hal prestasi siswa dan guru telah meraih banyak prestasi. Kepala RA At-Taqwa adalah ibu Siti Juwariyah, S.Ag dengan 8 orang guru dan 1 orang penjaga sekolah.

Pada umumnya, untuk menjalin silaturrahim dan komunikasi yang baik antara pihak sekolah dengan orang tua siswa, di suatu sekolah dibentuk sebuah organisasi. Saat ini beberapa nama organisasi yang berkembang adalah Komite, POMG, Dewan Sekolah, dan sebagainya. Berdasarkan hasil wawancara dengan kepala RA At-Taqwa Kota Cirebon (Selasa, 18 Oktober 2016) bahwa di RA At-Taqwa, kegiatan/organisasi perkumpulan tersebut mengacu kepada organisasi Persatuan Orang Tua Murid dan Guru atau yang lebih dikenal sebagai POMG. Organisasi inilah yang kemudian di RA At-Taqwa secara periodik, setiap satu bulan satu kali mengadakan kegiatan "Islamic Parenting"

Islamic Parenting di RA At-Taqwa diselenggarakan oleh Persatuan Orang tua Murid dan Guru (POMG) setiap satu bulan satu kali, tepatnya setiap hari Sabtu pada minggu keempat. POMG itu sendiri adalah wadah persatuan orang tua/wali murid RA yang dibentuk dan difasilitasi oleh RA At-Taqwa. Untuk itu kepengurusan POMG terdiri dari para orang tua murid itu sendiri. Keberadaan Kepala RA sebagai Pembina dan fasilitator kegiatan-kegiatan POMG.

Latar belakang Islamic Parenting di RA At-Taqwa berawal dari banyaknya orang tua murid yang berkonsultasi tentang berbagai kesulitan yang dihadapi dalam pendidikan dan pola pengasuhan anak-anak mereka. Atas dasar itu, RA At-Taqwa memfasilitasi pengurus POMG untuk mengadakan berbagai kegiatan yang bertujuan untuk memberikan wawasan, pemahaman dan berbagai pengalaman dalam hal pola pengasuhan anak-anak. Sehingga dapat terjalin 
sinergitas antara orang tua murid dengan pihak RA At-Taqwa dalam pola pendidikan anak yang lebih baik.

Para orang tua sangat berharap dengan kegiatan Islamic parenting yang diselenggarakan tiap bulan ini dapat menjadi bekal yang memadai bagi orang tua dalam membentuk karakter anak-anaknya di rumah. Semua orang tua mempunyai harapan yang sama, dengan menyekolahkan anak-anaknya di RA At-Taqwa dapat menjadikan anak-anak mereka menjadi anak yang soleh dan solehah, artinya anak-anak mereka bukan sekedar tumbuh kembang secara fisik melainkan secara psikis merekapun dapat berkembang secara seimbang.

\section{Implementasi Islamic Parenting dalam Pembentukan Karakter Anak Usia Dini di RA At-Taqwa Kota Cirebon}

a. Persiapan

Persiapan pelaksanaan "Islamic Parenting" yang diselenggarakan POMG tidak terlepas dari tujuan yang ingin dicapai oleh para orang tua. Antara lain sebagaimana yang disampaikan orang tua adalah untuk silaturrahim dan menambah wawasan keislaman serta pola-pola pengasuhan anak. Para orang tua yang tergabung dalam POMG sebelum pelaksanaan Islamic Parenting selalu berkonsultasi kepada Kepala RA At-Taqwa untuk membahas tema dan pemateri yang akan mengisi acara Islamic Parenting tersebut. Islamic Parenting dilaksanakan setiap satu bulan satu kali, yaitu setiap hari Sabtu minggu keempat pada setiap bulan. Dimulai jam 08.00 sd jam 10.00 WIB.

Materi Islamic parenting dirumuskan secara sederhana dalam tema-tema yang telah dimusyawarahkan oleh Pengurus POMG dengan pihak RA At-Taqwa dengan tema-tema: Ibadah Shalat, Akhlak terpuji dan Tercela, Mengenal masa aqil baligh, Mendidik anak dengan kasih sayang, Peranan Ayah dan Ibu dalam mendidik anak, Kedudukan anak dalam Alqur'an, Pendidikan anak Pranatal, Pendidikan aqidah untuk anak-anak, Anak belajar dari lingkungan terdekat, Tanggung jawab orang tua dalam mendidik anak, Tantangan dan ancaman bagi pendidikan Anak, Surga di bawah telapak kaki Ibu.

Setelah merumuskan tujuan dan materi yang akan dikaji dalam setiap pertemuan POMG, langkah berikutnya adalah mengkoordinasikannya dengan semua pihak terkait. Antara lain dengan seluruh orang tua murid RA At-Taqwa, Kepala RA At-Taqwa dan Dewan Guru, Narasumber yang akan mengisi materi sesuai jaduwal, dan perwakilan dari pihak Yayasan AtTaqwa. 
b. Pelaksanaan

Islamic parenting di RA At-Taqwa dilaksanakan pada hari Sabtu minggu keempat setiap bulan, dimulai pukul 08.00 sd. 10.00 WIB bertempat di RA setempat. Acara diawali dengan prakata Ketua POMG dan Kepala RA, dilanjutkan dengan pembacaan ayat suci Alqur'an yang dikumandangkan salah satu orang tua yang hadir. Berikutnya, narasumber yang bertugas menyampaikan materi Islamic parenting pada saat itu memulai presentasi sampai dengan selesai, Para peserta (orang tua/wali murid) menyimak dengan baik materi yang disaampaikan Narasumber. Penyampaian materi oleh narasumber berlangsung selama kurang lebih 25-30 menit. Kemudian dilanjutkan dengan sesi tanya jawab (dialog) seputar tema/pokok bahasan atau yang terkait dengan pola asuh anak-anak usia dini. Pertanyaan-pertanyaan dari orang tua murid yang muncul lebih banyak terkait pengalaman nyata mereka di lapangan sebagai seorang ibu dalam mengasuh anak-anak mereka, problem-problem yang sering dihadapi dan solusi yang dapat ditawarkan untuk mengatasi problem tersebut. Sehingga pendekatan kegiatan Islamic Parenting di RA At-Taqwa lebih bersifat "problem solver"

c. Evaluasi

Dalam tataran praktis, evaluasi kegiatan Islamic Parenting di RA At-Taqwa Kota Cirebon ini terbagi dalam 2 (dua) jenis evaluasi. Diantaranya evaluasi proses, yang dilakukan secara langsung ketika kegiatan berlangsung yang dilakukan oleh Kepala RA At-Taqwa dengan pengurus inti POMG. Apakah kegiatan tersebut berjalan dengan lancar, misalnya tentang kehadiran peserta/orang tua/wali, narasumber, ketepatan waktu, keaktifan orang tua selam proses berlangsung.

d. Tantangan yang Dihadapi dalam Pola Pengasuhan Anak

Orang tua/wali murid RA At-Taqwa dalam melakukan pengasuhan terhadap anakanaknya tidak terlepas dari berbagai tantangan atau kendala yang dihadapi. Dari beberapa responden yang peneliti wawancarai, dapat diperoleh gambaran, antara lain : Anak tidak mau belajar, Anak tidak mau sholat, Harus selalu menunggu perintah orang tua, Tidak mau mengikuti perintah orang tua, Kondisi anak kurang moods, Anak-anak mengantuk, Anak malas-malasan, Anak merasa kecapean.

e. Langkah-langkah Orang tua dalam Mengatasi kendala dalam pengasuhan anak usia dini

Adapun langkah-langkah yang dilakukan orang tua dalam mengatasi kendala dalam pengasuhan anak usia dini adalah membujukanak secara pelan-pelan, dihadapi dengan sabar, anak dibiasakan untuk sholat, mengaji dan menghafal, diberikan pengertian tentang akibat 
perbuatan yang dilakukan, belajar memahami kaarakter anak, Memberikan penjelasan tentang hukum shalat, Memahami kondisi anak, sedang moods atau tidak, Membiarkan anak terlebih dahulu, maunya apa? Kemudian diarahkan sesuai keingin orang tua.

\section{f. Dampak Islamic Parenting terhadap Pembentukan Karakter Anak Usia Dini}

Islamic parenting yang diselenggarakan oleh POMG RA At-Taqwa memberikan dampak yang sangat positif kepada orang tua dalam melakukan pola asuh terhadap putera/putera mereka. Diantara dampak yang dirasakan langsung oleh orang tua murid RA At-Taqwa dalam membentuk karakter anak-anak usia dini (RA), sebagaimana tergambar dalam hasil wawancara dengan orang tua murid RA At-Taqwa sebagai berikut:

1. Membantu anak-anak lebih disiplin

Islamic parenting, dampaknya sangat positif, karena dari kegiatan ini kami dapat membiasakan anak-anak bangun lebih awal, anak bangun lebih pagi. (Ibu Yeni). "dampaknya positif mendidik anak untuk lebih disiplin, taat beribadah dan membiasakan hal-hal yang baik." (Ibu Retno/Humas POMG)

2. Mengokohkan Kekeluargan dan Berbagi pengalaman

Islamic Parenting di RA At-Taqwa dapat menjadikan suasana kekeluargaan dan silaturrahim diantara orang tua murid menjadi lebih kokoh; selain diantara mereka pun dapat saling bertukar pengalaman dalam melakukan pola pengasuhan anak-anak mereka.

3. Membangun kebiasaan positif

Banyak hal yang diperoleh orang tua dari hasil parenting yang dilaksanakan setiap bulan sekali di RA At-Taqwa, antara lain mendorong orang tua agar memberikan pembiasaanpembiasaan yang positif dalam kehidupan sehari-hari di rumah, dari mulai bangun pagi lebih awal, menyiapkan jadwal harian anak, dan taat menjalankan ibadah, seperti shalat dan sebagainya."mendapat wawasan tentang cara mendidik anak dengan benar, dengan memberikan teladan dan contoh nyata dalam kegiatan harian anak, seperti apa yang seharusnya”. (Ibu Yuli/Humas POMG).

"Hasil perenting, alhamdulillah dapat khabar positif mengenai kemajuan kognitif anak maupun karakter anak. Karena kami menekankan kepada orang tua/wali murid bahwa keteladanan orang tua sangatlah berpengaruh terhadap karakter anak. Dengan kita memberikan contoh yang baik, Insya Allah anak akan menerapkan dalam kegiatan keseharian mereka". (Kepala RA At-Taqwa/Juju J) 


\section{SIMPULAN}

Islamic Perenting di RA At-Taqwa adalah kegiatan orang tua/wali murid RA yang difasilitasi pihak sekolah/RA untuk mengadakan kegiatan presentasi ilmiah ataupun pengkajian tentang berbagai tema terkait pola pendidikan dan pengasuhan anak usia dini (RA), dengan tujuan untuk memberikan tambahan wawasan pengetahuan teoritik dan pengalaman praktis kepada orang tua/wali murid dalam mendidik anak-anak mereka. Kegiatan ini dilaksanakan oleh Persatuan Orang tua Murid dan Guru (POMG) setiap bulan sekali pada hari Sabtu minggu ke-4, dimulai jam 08.00 sd. Jam 10.00 WIB di RA setempat, dengan menghadirkan narasumber yang dianggap kompeten dibidangnya.

Orang tua/wali murid RA dalam melakukan pola pengasuhan anak terhadap anak-anak mereka (usia dini/RA) tidak luput dari berbagai kendala yang dihadapi, antara lain anak tidak mau belajar; anak tidak mau sholat; anak selalu menunggu perintah orang tua; Tidak mau mengikuti perintah orang tua; Kondisi anak kurang moods; Anak-anak mengantuk; Anak malasmalasan; Anak merasa kecapean;

Langkah-langkah yang dilakukan orang tua/wali murid RA At-Taqwa Kota Cirebon, dalam mengatasi berbagai kendala sebagaimana tersebut di atas. Berdasarkan wawasan dan pengalaman yang orang tua/wali murid, antara lain dengan cara: a) Memahami karakter anak; b) Menguatkan kesabaran; c) Dengan strategi membujuk anak secara pelan-pelan; d) Memberikan pengertian dan penjelassan dengan baik; e) Memberikan reward dan punishment; f) Memberikan contoh teladan dan pembiasaan; g) Memahami dan mengerti kondisi anak.

Dampakyang dirasakan orang tua/wali murid RA At-Taqwa setelah mengikuti kegiatan Islamic parenting dalam pembentukan karakter anak usia dini (RA), antara lain mereka merasa terbantu memiliki pola untuk lebih mendisiplinkan anak anak; dapat mengokohkan persaudaraan/silaturrahim; saling sharing pengalaman dalam melakukan pola pengassuhan anak antara orang tua yang satu dengan yang lainnya; dan membantu proses pembentukan $\mathrm{k} \quad$ saankebiasaan positif.

\section{DAFTAR PUSTAKA}

Abdurrahman, Jamal Syaikh. 2010. Islam Parenting. Solo: Aqwam Media Profetika. Cet. $\mathrm{Ke}-1$

Adisusilo, Sutarjo, J.R. 2014. PembelajaranNilai-Karakter: Konstruktivismedan VCT sebagaiInovasiPendekatanPembelajaranAfektif. Jakarta: Rajawali Press, Cet. Ke-3

Asmawati, Suhid. 2009.Pendidikan Akhlak dan Adab Islam. Kuala lumpur : Mazizi

Implementasi Islamic Parenting Dalam Membentuk Karakter Anak Ahmad Yani, Ery Khaeriyah,
Usia Dini


Ath-Thusy, Abu Hamid Muhammad bin Muhammad bin Muhammad Al-Ghazali. 20... IhyaUlumiddin

Aunillah, Nuria Isna. 2015. MembentukKarakterAnakSejakJanin. Yogyakarta: FlashBooks, Cet. $\mathrm{Ke}-1$

Cahyono, Rudi. 2015. Daily Parenting "Menjadikan Orang Tua Pendidik yang Luar Biasa”. Jakarta: Pandamedia

Chakra, Fita. 2013. Diari Parenting. Jakarta: Bhuana Ilmu Populer

Hadi, Sutrisno. 1984.Metodologi Penelitian Reserch II, Jakarta: Puspa Swara.

Haris, Abdul dan Abdul MajidKhon. 2012. Al-Hadits(EdisiRevisi). Jakarta: DirektoratJenderalPendidikan Islam Kementerian Agama RI

Helmawati. 2014. Pendidikan Keluarga Teoritis dan Praktis, Bandung: PT Remaja Rosdakarya, Cet. 1

Jay, Roni. 2009. Pedoman Penting Membesarkan Anak. Jakarta: Erlangga

Kartono, Kartini. 2007. Psikologi Anak. Bandung: Mandar Maju

Mahasiswa, Jurusan PGRA semester II. 2015 Pendidikan Anak dalam Keluarga. Cirebon: Tanpa Penerbit

Mansur, Kahar. 1994. Membina Moral dan Akhlak. Jakarta: Rineka Cipta

Mardalis, 2002, MetodePenelitianSuatuPendekatan Proposal, Jakarta: BumiAksara.

Megawangi,Ratna. 2007.CharacterParentingSpace, Menjadi Orang Tua Cerdas untukMembangkitkanKarakterAnak,Bandung:MizanMediaUtama

Moleong, Lexy J., 1999, MetodePenelitianKualitatif, Bandung: RemajaRosdakarya

Mursid, 2015, Pengembangan Pembelajaran Paud, Bandung: RemajaRosdakarya

Muslim, Shohih Muslim dalam Maktabah Asy-Syamilah

Purwandani, Kristi, 1999, PendekatanKualitatifUntukPenelitianPerilakuManusia, Jakarta: LPSPPP.

Puspitarini, Henny. 2015. HypnoparentingIslami: MendidikAnakBerbasisQur'ani. Klaten: Caesar Media Pustaka

Rachman, Fauzi. 2014. Islamic Teen Parenting. Jakarta: Erlangga

Ratuliu, Mona. 2015. ParenThink. Jakarta: Noura Books, Cet. ke-1

Salim,Peter.Tth. TheContemporaryEnglish-IndonesiaDictionary, Jakarta:ModernEnglishPress

Sangarimbun, Masri\& Effendi Sofian, 1999, MetodePenelitian Survey, Jakarta: LP3ES.

Shohib,M.1998. PolaAsuhOrangTua, Jakarta:RinekaCipta

Implementasi Islamic Parenting Dalam Membentuk Karakter Anak Ahmad Yani, Ery Khaeriyah,
Usia Dini


Sukmadinata,Nana Syaodih. 2004.Metode Penelitian Pendidikan. Bandung: PT Remaja Rosdakarya,

Surya, Mohammad. 2004. PsikologiPembelajaran danPengajaran. Bandung: PustakaBaniQuraisy.

Tirtayani, Luh Ayu, et. Al, 2014. PerkembanganSosialEmosionalPadaAnakUsiaDini. Yogyakarta: GrahaIlmu

Zaman, Saeful. 2008. Melejitkan Potensi Akhlak pada Anak. Bandung: Azzam Media Abadi. Cet. Ke-1

Zainuddin, et al, 1991. Seluk-Beluk Pendidikan dari Al-Ghazali.Jakarta: Bumi Aksara

Zarman,Wendi, 2011. TernyataMendidikAnak Cara RasulullahItuMudahdanlebihEfektif. Bandung: Ruang Kata 